\title{
Physicochemical properties, total phenolic content, and antioxidant activity of chestnut, rhododendron, acacia and multifloral honey
}

\author{
Nurettin Akgün ${ }^{1}$. Ömer Faruk Çelik ${ }^{2}$ (D) Latif Kelebekli $^{1}$ (i)
}

Received: 8 January 2021 / Accepted: 19 April 2021 / Published online: 26 April 2021

(c) The Author(s), under exclusive licence to Springer Science+Business Media, LLC, part of Springer Nature 2021

\begin{abstract}
The aim of this study is to investigate the physicochemical properties, antioxidant activities, and total phenolic contents of the plateau (multifloral), chestnut, rhododendron, and acacia honey collected from Ordu province in Turkey. The rhododendron honey had the highest acidity $(\mathrm{p}<0.05)$ while the chestnut honey showed the highest conductivity $(1.13 \pm 0.25 \mathrm{mS} / \mathrm{cm})$ among all $(\mathrm{p}<0.05)$. The highest diastase activities and the lowest HMF contents were determined in the multifloral and chestnut honey. Considering the DPPH and FRAP assays, the multifloral honey showed the highest antioxidant activity. Accordingly, the highest total phenolic content was determined in the multifloral honey followed by rhododendron, chestnut, and acacia honey. A moderate correlation was determined between the total phenolic content and antioxidant activities $(r=0.575$ for FRAP and $r=0.697$ for DPPH). Consequently, the plateau honey could be recommended for nutritional and health purposes due to its relatively higher antioxidant activity and total phenolic content together with relatively lower HMF content and higher diastase activity. Considering that Ordu is the largest honey producer city in Turkey, the second top honey producer country, this work could shed light for future studies and be taken as a reference providing insights on the characteristics of different types of honey for both local and worldwide producers.
\end{abstract}

Keywords Diastase $\cdot$ DPPH $\cdot$ FRAP $\cdot$ HMF $\cdot$ Plateau honey $\cdot$ Proline

\section{Introduction}

Honey is the most consumed bee product around the world for nutritional and curative purposes among the valuable arts that honeybees (Apis spp.) generate including propolis, pollen, royal jelly, beeswax, honeybee venom, and bee bread (perga). Honey contains approximately 200 identified compounds with a typical composition of $38 \%$ fructose, $31 \%$ glucose, $10 \%$ other sugar types, $18 \%$ water, and $3 \%$ other substances. However, this $3 \%$ is considered as the most important portion of honey residing valuable components such as carotenoids and phenolics [1,2].

Due to its therapeutic features, there are many studies available on the beneficial effects of honey on human biological processes including antioxidant $[1,3]$, antimicrobial

Latif Kelebekli

lkelebekli@yahoo.com; lkelebekli@odu.edu.tr

1 Department of Chemistry, Faculty of Sciences and Arts, Ordu University, 52200 Ordu, Turkey

2 Department of Food Engineering, Faculty of Agriculture, Ordu University, 52200 Ordu, Turkey
[4-6], wound healing [7, 8], antidiabetic [9, 10], antiinflammatory [11, 12], and anticancer [13, 14] activities. Furthermore, owing to its antiviral effects [15], honey has been applied in clinical trials in the USA and Egypt hoping to discover potential curing effects against the current COVID-19 pandemic [16]. Most of these benefits of honey are attributed to its unique phenolic composition which depends mainly on seasonal and environmental factors [17]. Phenolic profiles of different honey types were determined by Kivrak et al. [18] and Can et al. [19]. For example, the main phenolic compounds of the rhododendron honey were determined as benzoic acid derivatives, coumaric, caffeic, and ferulic acids whereas benzoic acid derivatives, vanillic, protocatechuic, and coumaric acids were the ones detected in the chestnut honey.

Climatic conditions and geographical location makes Turkey a favorable country for honey production. Therefore, it is home to both unifloral and multifloral honey from nectar and honeydew. According to statistical data, Ordu, harboring 573.358 hives, is the largest honey-producer city of Turkey with an annual honey production of 17.057 tons [20]. However, the information on essential physical, chemical, 
and biological properties of honey from this region is limited. Honey characteristics have been shown to depend on the nectar type as well as the region [21, 22]. Therefore, the purpose of this study is to evaluate the physicochemical and biochemical properties of four different types of honey including chestnut, acacia, rhododendron, and a multifloral (locally known as plateau honey) honey collected from the hives located in Ordu province.

\section{Materials and methods}

\section{Honey samples}

Honey samples, consisted of four different types, were supplied by three different local beekeepers (12 samples in total) from the regions and approximate coordinates indicated in the brackets as follows: namely chestnut honey (Gurgentepe: 40.78951, 37.60017), acacia (Altınordu: 40.98554, 37.87924), rhododendron (Korgan: 40.82925, 37.34412), and multifloral (known as plateau honey among locals) honey (Mesudiye: 40.446381, 37.77368) (Fig. 1). To avoid the temperature effect, the samples were stored at room temperature away from sunlight until analyses.

\section{Moisture content}

The moisture content was determined using the refractometric method suggested by Bogdanov [23]. Briefly, a homogenized honey sample was put in a closed container and placed in a water bath set to $50 \pm 0.5^{\circ} \mathrm{C}$ to allow all the sugar crystals to be dissolved prior to the analysis. The sample was then cooled to room temperature and stirred again. The refractive indices of honey samples were read using a refractometer (RX-50000X, Atago, Japan) at $20^{\circ} \mathrm{C}$ and corresponding moisture contents were recorded [24].

\section{Free acidity}

Titrimetric analysis was performed to determine free acidity following the method given by Bogdanov [23]. Basically, the acidity was calculated based on the volume of consumed $0.1 \mathrm{M} \mathrm{NaOH}$ for titration of the diluted honey sample $(10 \mathrm{~g}: 75 \mathrm{~mL}$ distilled water) to reach a $\mathrm{pH}$ of 8.3 and the results were expressed as milliequivalents per $\mathrm{kg}$ of honey.

\section{Electrical conductivity (EC)}

A conductivity meter (H1763100, Edge, Hanna Instruments Inc., RI, USA) was used for EC measurements of honey samples $[20 \%(\mathrm{w} / \mathrm{v})$ in distilled water]. The cell constant was determined using $0.1 \mathrm{M}$ potassium chloride solution. All measurements were performed at $20{ }^{\circ} \mathrm{C}$ in triplicate, and the means are expressed as MilliSiemens per centimeter $(\mathrm{mS} / \mathrm{cm})$.

\section{Diastase activity}

The diastase activity of honey samples was determined following the Phadebas method according to the procedure of Bogdanov [23] with small modifications. Honey sample (1 $\mathrm{g}$ ) was dissolved in acetate buffer to a final volume of $100 \mathrm{~mL}$. Then, $5 \mathrm{~mL}$ of this solution was transferred to a test tube and placed in a water bath at $40{ }^{\circ} \mathrm{C}$ for $5 \mathrm{~min}$. A Phadebas tablet (Pharmacia Diagnostics AB, Uppsala, Sweden) was added to the solution and vortexed for $10 \mathrm{~s}$. The solution was transferred back to the water bath and incubated for $30 \mathrm{~min}$. The reaction was terminated by adding $1 \mathrm{~mL}$

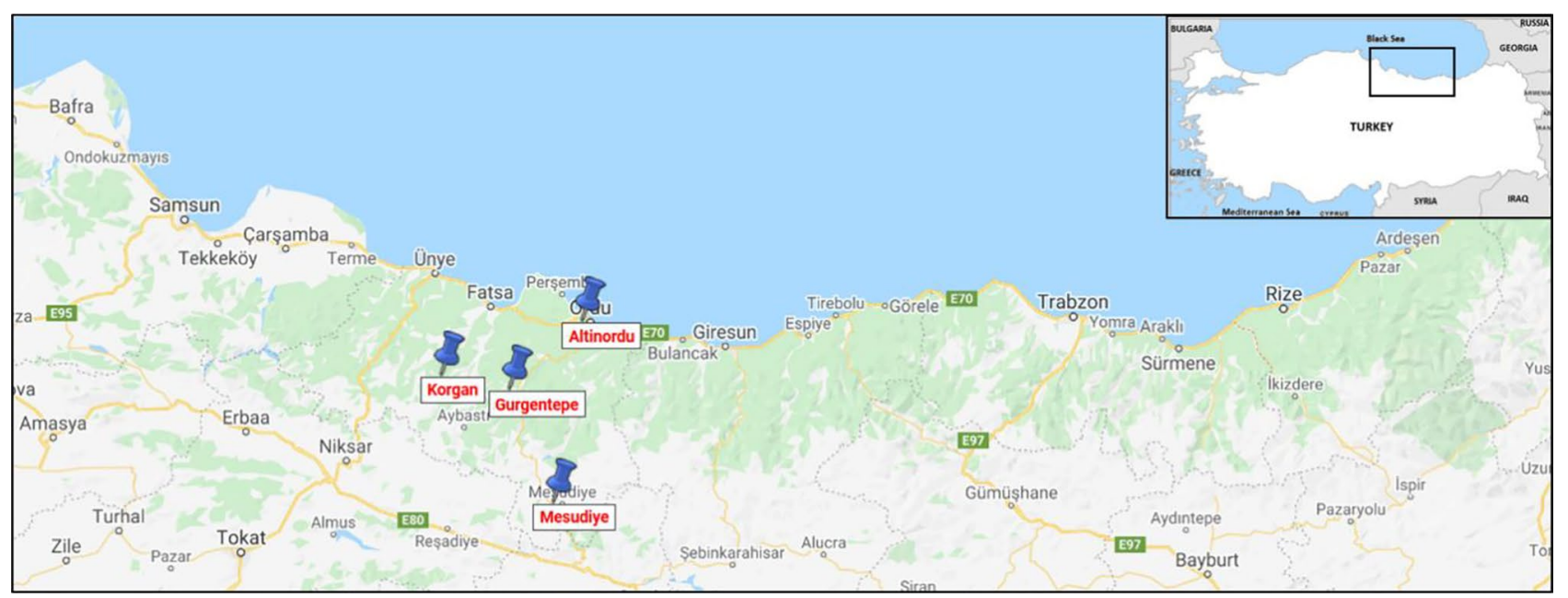

Fig. 1 Locations of collected honey samples 
of $0.5 \mathrm{M} \mathrm{NaOH}$ flowed by vortexing for $5 \mathrm{~s}$. The solutions were centrifuged ( $3662 \times g$ for $5 \mathrm{~min}$ ) and absorbances were recorded at $620 \mathrm{~nm}$ wavelength against blank. The diastase activity was calculated from the absorbance readings and expressed in Schade units using Eqs. 1 and 2 given below [25].

Diastase activity (as Schade unit)

$=28.2 \times \Delta \mathrm{A} 620+2.64($ if $8 ;$ diastase units; 40$)$

Diastase activity (as Schade unit)

$=35.2 \times \Delta \mathrm{A} 620-0.46($ if diastase units $\leq 8)$

\section{Hydroxymethylfurfural (HMF) content}

HMF content was determined using a reverse-phase HPLC equipped with UV detection system and a C18 column (ODS Hypersil C18, Thermo Scientific, Inc., MA, USA) as explained by Bogdanov [23]. The method is based on the dissolution of honey in water $(10 \mathrm{~g}$ to a final volume of $50 \mathrm{~mL})$ and its filtration through a membrane filter $(0.45 \mu \mathrm{m})$ prior to injection to the HPLC system and signal detection at $285 \mathrm{~nm}$ wavelength.

\section{Proline content}

Proline content was determined according to the official TS 13357 method [26]. The method involves the formation of a colored complex as a result of the reaction between proline and ninhydrin and spectrophotometric measurement of the color intensity at $510 \mathrm{~nm}$ wavelength. The proline content is expressed as $\mathrm{mg}$ proline $/ \mathrm{kg}$ honey.

\section{DPPH (1,1-diphenyl-2-picrylhydrazyl) assay}

The DPPH radical scavenging activity of honey samples was determined as a measure of antioxidant activity according to Bergamo et al. [27] with some modifications. Briefly, each honey sample $(2 \mathrm{~g})$ was dissolved in $10 \mathrm{~mL}$ of methanol using a vortex-mixer. An aliquot of this solution $(3 \mathrm{~mL})$ was mixed with a freshly prepared DPPH solution $(0.1 \mathrm{mM}$ in $80 \%$ methanol). The mixture was kept in the dark at room temperature for $30 \mathrm{~min}$ and absorbance values at $517 \mathrm{~nm}$ were recorded. All readings were made in triplicate and results are expressed as the inhibition values [Inhibition (\%) $\left.=100 \times\left(\mathrm{Abs}_{\text {blank }}-\mathrm{Abs}_{\text {sample }}\right) / \mathrm{Abs}_{\text {blank }}\right][28]$.
Ferric ions $\left(\mathrm{Fe}^{3+}\right)$ reducing antioxidant power assay (FRAP)

The reducing powers of samples were determined by the method of Gülçin et al. [29]. Briefly, a $240 \mu \mathrm{L}$ sample solution, from the stock honey sample solutions prepared for DPPH assay, was mixed with sodium phosphate buffer (2.5 mL, 0.2 M, pH 6.6) and potassium ferricyanide $\left[\mathrm{K}_{3} \mathrm{Fe}(\mathrm{CN})_{6}\right](2.5 \mathrm{~mL}, 1 \%)$. The mixture was incubated at $50{ }^{\circ} \mathrm{C}$ for $20 \mathrm{~min}$ followed by the addition of $2.5 \mathrm{~mL}$ of trichloroacetic acid (10\%). Then, this solution was mixed with distilled water $\left(2.5 \mathrm{~mL}\right.$ each) and $0.5 \mathrm{~mL}$ of $\mathrm{FeCl}_{3}$ $(0.1 \%)$, and the absorbance was measured at $700 \mathrm{~nm}$ using a spectrophotometer. Trolox was used as the standard compound, all readings were made in triplicate and the antioxidant activity is expressed as mg trolox equivalent (TE)/g honey.

\section{Total phenolic content (TPC)}

The total phenolic content of the honey samples was determined with the Folin-Ciocalteu method as described by Gülçin et al. [29]. A $1 \mathrm{~mL}$ aliquot of honey stock solution was diluted with distilled water $(46 \mathrm{~mL})$, then $1 \mathrm{~mL}$ of Folin-Ciocalteu reagent was added and mixed thoroughly. Three minutes later, $3 \mathrm{~mL}$ of $\mathrm{Na}_{2} \mathrm{CO}_{3}(2 \%)$ was added and the mixture was diluted to a final volume of $50 \mathrm{~mL}$, followed by incubation at room temperature in the dark for $2 \mathrm{~h}$ with intermittent shaking. The absorbance readings at $760 \mathrm{~nm}$ were recorded. A standard curve was plotted using gallic acid to calculate the concentration of total phenolic compounds in the honey (mg gallic acid equivalent (GAE)/g honey).

\section{Statistical analysis}

All analyses were performed in triplicate. Statistical analyses were performed using Minitab 17 (Minitab Inc., State College, PA, USA). One-way analysis of variance (ANOVA) through the general linear model was applied $(\alpha=0.05)$. For comparison, significant differences $(p<0.05)$ between the means were further analyzed using the Tukey Test. All values were normally distributed ( $p>0.05$ ) according to the Anderson-Darling normality test hence the Pearson's correlation coefficient was applied to understand the relationship between TPC, DPPH, and FRAP results. 


\section{Results and discussion}

\section{Moisture}

The moisture content is an indicator of the stability and shelf life of honey. The lower the moisture content, due to less favorable conditions for fermentation and spoilage by microorganisms, the higher the stability and resistance to granulation of honey is. Also, it gives an idea on the botanical and geographical origin of the nectar, climatic conditions, the season of harvesting, adulteration by sellers/producers, processing and storage conditions [30, 31]. It is recommended that honey should be stored at $10-16{ }^{\circ} \mathrm{C}$ under a relative humidity less than $65 \%$ in a hermetically sealed container to minimize moisture capture from the environment [32].

The moisture content of honey samples ranged between 14.45 and $21.62 \%$ with an average value of $18.43 \pm 1.82 \%$ (Table 1). This value is in compliance with the regulations of TFC [33] and EU [34] which limited the moisture content to $20 \%$ at maximum. The highest and the lowest moisture contents were determined in the rhododendron $(18.89 \pm 1.16 \%)$ and acacia $(17.99 \pm 3.11 \%)$ honey, respectively. However, the moisture content was not affected significantly by honey type $(p=0.789)$ and there was no significant difference between honey types in terms of moisture content. These moisture contents are similar to the ones obtained in the studies by Kivrak et al. [18], Šarić et al. [35], and Zappala et al. [36] for chestnut, rhododendron, and acacia honey.

Table 1 Physicochemical characteristics of honey samples

\begin{tabular}{lllll}
\hline Parameters & Honey type & Mean value \pm SD & Min & Max \\
\hline Moisture (\%) & Multifloral honey & $18.39 \pm 1.30^{\mathrm{a}}$ & 17.48 & 20.12 \\
& Chestnut & $18.45 \pm 1.17^{\mathrm{a}}$ & 17.38 & 19.96 \\
& Acacia & $17.99 \pm 3.11^{\mathrm{a}}$ & 14.45 & 21.62 \\
& Rhododendron & $18.89 \pm 1.16^{\mathrm{a}}$ & 17.92 & 20.42 \\
& - & $18.43 \pm 1.82$ & 14.45 & 21.62 \\
Free Acidity & Multifloral honey & $24.67 \pm 4.61^{\mathrm{b}}$ & 19 & 31 \\
(meq/kg) & Chestnut & $17.33 \pm 5.15^{\mathrm{b}}$ & 12 & 25 \\
& Acacia & $16.33 \pm 3.00^{\mathrm{b}}$ & 12 & 21 \\
& Rhododendron & $34.33 \pm 13.04^{\mathrm{a}}$ & 16 & 44 \\
& - & $23.17 \pm 10.26$ & 12 & 44 \\
Conductivity & Multifloral honey & $0.20 \pm 0.00^{\mathrm{b}}$ & 0.20 & 0.21 \\
(mS/cm) & Chestnut & $1.13 \pm 0.25^{\mathrm{a}}$ & 0.80 & 1.31 \\
& Acacia & $0.19 \pm 0.06^{\mathrm{b}}$ & 0.14 & 0.27 \\
& Rhododendron & $0.32 \pm 0.03^{\mathrm{b}}$ & 0.28 & 0.36 \\
& - & $0.46 \pm 0.42$ & 0.14 & 1.31 \\
\hline
\end{tabular}

Mean values in the same column followed by different uppercase letters are significantly different $(\mathrm{p}<0.05)$

$S D$ standard deviation

\section{Free acidity}

Acidity is an important criterion that affects the organoleptic and physical properties such as color and conductivity. More than 30 different acids were identified in honey. Although nectar is a source of organic acids (citric, malic, oxalic), the majority of the acid is generated through the enzymatic activity of bees e.g. gluconic acid which is formed through break down of glucose by the enzyme glucose oxidase. The type of organic acids present in honey is important since the dominant organic acid may give hints about the botanical origin of the honey [37]. Furthermore, high acidity is usually associated with dark-colored honey [31]. The free acidity values of the honey samples are given in Table 1 . The honey type affected the acidity levels of honey samples significantly $(\mathrm{p}<0.001)$. The average acidity was $23.17 \pm 10.26 \mathrm{meq} / \mathrm{kg}$ while the rhododendron and multifloral honey had the highest acidities, respectively. The rhododendron honey had a significantly higher acidity level than its counterparts $(p<0.05)$, whereas, there was no significant difference between acacia, chestnut, and multifloral honey regarding the acidity $(\mathrm{p}>0.05)$. These values are under the limit of $50 \mathrm{meq} / \mathrm{kg}$ honey set by both EU [34] and TFC [33]. Considering these results, the relatively low acidity of chestnut is reasonable since it is known to have higher $\mathrm{pH}$ (5-6) hence less acidity compared to other blossom honey which usually have a $\mathrm{pH}$ value in the range of 3.3 to 4.6 [23]. Similarly, Kivrak et al. [18] found that rhododendron honey had higher acidity with respect to chestnut and acacia honey, respectively. On the other hand, Küçük et al. [38] found that rhododendron had slightly lower acidity than chestnut. Although high acidity could protect the honey against microbial spoilage, it should be kept in mind that the presence of a high levels of acids, especially acetic acid, may also indicate spoilage by yeast fermentation.

\section{Electrical conductivity (EC)}

The EC values of honey samples are presented in Table 1 . The honey type was found to be a significant factor affecting the EC value $(p<0.001)$. Among all, chestnut honey stands out regarding its EC value $(1.13 \pm 0.25 \mathrm{mS} / \mathrm{cm})$ while the others have similar EC values $(0.19-0.20$ and $0.32 \mathrm{mS} /$ $\mathrm{cm})$. The EC value is directly proportional to the mineral and acid content of honey and has been commonly used to understand the botanical origin of honey. For example, although there are exceptions for certain types of honey, the $\mathrm{EC}$ of blossom honey must be lower than $0.8 \mathrm{mS} / \mathrm{cm}$, on the contrary, chestnut and honeydew honey must have an EC higher than $0.8 \mathrm{mS} / \mathrm{cm}$ according to the EU [34]. Hence, these results are within the limits of the EU [34]. Similarly, Thrasyvoulou and Manikis [39] and Šarić et al. [35] determined an average of 1.54 and $1.27 \mathrm{mS} / \mathrm{cm}$ EC from Greek 
and Croatian chestnut honey, respectively. Similar results were also obtained for chestnut, acacia, and rhododendron honey in different studies $[18,19,36]$.

\section{Diastase activity}

As presented in Table 2, the honey samples presented a broad range of diastase number (4.00-39.3) and the effect of honey type on the diastase number was found significant $(p=0.001)$. The highest diastase activity was determined in the multifloral honey $(26.17 \pm 10.39)$. Diastase is one of the three main enzymes, together with invertase and glucose oxidase, found in honey. Enzyme activity, more specifically diastase activity, is highly dependent on environmental temperature. Moreover, together with HMF content, diastase activity is an indicator of freshness [40]. Storage under warm conditions and high-temperature treatments of honey would result in lower diastase activity. For example, it was reported that heating acacia honey $\left(80{ }^{\circ} \mathrm{C}\right.$ for $\left.60 \mathrm{~min}\right)$ reduced diastase activity by around $20 \%$ [41]. The diastase half time is reported as 35 years, 4 years, and 200 days when stored at 10,20 , and $30{ }^{\circ} \mathrm{C}$, respectively [32]. Therefore, this result is reasonable considering that multifloral honey is actually collected from high altitude plateaus which have relatively lower temperatures. Furthermore, plateaus can be conceived as slow nectar flux and less fertile environments enabling

Table 2 Diastase activity, HMF and proline contents of honey samples

\begin{tabular}{|c|c|c|c|c|}
\hline Parameters & Honey type & Mean value $\pm S D$ & Min & Max \\
\hline \multirow[t]{5}{*}{ Diastase number } & $\begin{array}{c}\text { Multifloral } \\
\text { honey }\end{array}$ & $26.17 \pm 10.39^{\mathrm{a}}$ & 15.80 & 39.30 \\
\hline & Chestnut & $21.10 \pm 2.29^{\mathrm{ab}}$ & 19.10 & 24.10 \\
\hline & Acacia & $13.67 \pm 2.99^{\mathrm{bc}}$ & 10.80 & 17.50 \\
\hline & Rhododendron & $11.47 \pm 6.92^{\mathrm{c}}$ & 4.00 & 19.90 \\
\hline & $\overline{\mathrm{X}} \pm \mathrm{SD}$ & $18.10 \pm 8.62$ & 4.00 & 39.3 \\
\hline \multirow[t]{5}{*}{$\begin{array}{l}\mathrm{HMF} \\
(\mathrm{mg} / \mathrm{kg})\end{array}$} & $\begin{array}{l}\text { Multifloral } \\
\text { honey }\end{array}$ & $3.64 \pm 2.09^{c}$ & 1.09 & 5.93 \\
\hline & Chestnut & $1.59 \pm 1.32^{\mathrm{c}}$ & 0.17 & 3.22 \\
\hline & Acacia & $11.83 \pm 4.17^{\mathrm{a}}$ & 8.31 & 17.34 \\
\hline & Rhododendron & $8.02 \pm 1.71^{\mathrm{b}}$ & 6.23 & 11.00 \\
\hline & $\overline{\mathrm{X}} \pm \mathrm{SD}$ & $6.27 \pm 4.71$ & 0.17 & 17.34 \\
\hline \multirow[t]{5}{*}{$\begin{array}{l}\text { Proline } \\
(\mathrm{mg} / \mathrm{kg})\end{array}$} & $\begin{array}{c}\text { Multifloral } \\
\text { honey }\end{array}$ & $692.67 \pm 79.53^{\mathrm{a}}$ & 609 & 796 \\
\hline & Chestnut & $758.56 \pm 67.73^{\mathrm{a}}$ & 688 & 845 \\
\hline & Acacia & $357.00 \pm 34.38^{\mathrm{b}}$ & 312 & 393 \\
\hline & Rhododendron & $535.00 \pm 377.91^{\mathrm{ab}}$ & 204 & 1033 \\
\hline & $\overline{\mathrm{X}} \pm \mathrm{SD}$ & $585.81 \pm 245.24$ & 204 & 1033 \\
\hline
\end{tabular}

Mean values in the same column followed by different uppercase letters are significantly different $(\mathrm{p}<0.05)$

$S D$ standard deviation bees more time to process the nectar hence higher enzyme levels are observed in honey [31]. Acacia and rhododendron honey had significantly lower diastase activity compared to multifloral and chestnut honey $(\mathrm{p}<0.05)$. Also, it could be speculated that acacia and rhododendron, as plants, may carry relatively less diastase since diastase in honey not only originates from the bee but also from the plants [42]. All honey samples possessed diastase numbers higher than 8 with an average of $18.10 \pm 8.62$ thereby complying with the standards [33, 34]. Similarly, Kivrak et al. [18] and Zappala et al. [36] determined that chestnut honey had higher diastase activity than acacia honey. However, diastase activity of rhododendron honey was found to be the highest followed by multifloral and chestnut honey (17.7), respectively in a study by Küçük et al. [38] while Can et al. [19] found that acacia honey had the highest diastase activity followed by rhododendron and chestnut respectively. These differences could be ascribed to climatic and floral differences of the regions where honey is harvested in different studies performed.

\section{Hydroxymethylfurfural (HMF) content}

HMF is a chemical compound generated from sugar degradation, Maillard or caramelization, and its concentration is increased with heat treatment/exposure [43]. The HPLC method was found to be more appropriate for HMF determination in honey among the methods applied so far since, unlike UV-based methods, it does not interfere with the substances formed through heat and/or storage damage [36]. However, high HMF could also be found in honey harvested from warm regions [44]. Since fresh honey contains no or traces of HMF low HMF content is usually attributed to freshness $[45,46]$. The HMF contents of honey samples are given in Table 2. The HMF content of honey was significantly affected by honey type $(\mathrm{p}<0.001)$. The lowest HMF content was determined in the chestnut honey $(1.59 \pm 1.32 \mathrm{mg} / \mathrm{kg})$ while the highest one was in the acacia honey $(11.83 \pm 4.17 \mathrm{mg} / \mathrm{kg})$. In order for a $\mathrm{kg}$ of honey to reach to a level of $40 \mathrm{mg} \mathrm{HMF}$, which is the highest level of HMF allowed by TFC [33] and EU [34], 2-4 years is required when stored at $20^{\circ} \mathrm{C}$ Bogdanov [32]. Consequently, all honey samples possessed an HMF level inside the limits. Sakač et al. [47] determined an average of $2.57 \mathrm{mg} / \mathrm{kg}$ HMF concentration for 15 acacia honey collected from Serbia. Out of 17 Moroccan multifloral honey samples, HMF level was determined as $12.91 \mathrm{mg} / \mathrm{kg}$ in a study by Chakir et al. [48]. Can et al. [19] found that HMF content of acacia $(12.56 \mathrm{mg} / \mathrm{kg})$ was higher than those of chestnut $(9.28 \mathrm{mg} /$ $\mathrm{kg})$ and rhododendron $(3.20 \mathrm{mg} / \mathrm{kg})$ honey, respectively. In another study, the HMF content of chestnut honey was determined to be higher than rhododendron and multifloral honey, respectively [38]. Honey types are lined up as 
rhododendron $>$ acacia $>$ chestnut based on their HMF contents by Kivrak et al. [18]. As listed here, different types of honey are associated with high levels of HMF content in different studies. Therefore, it is difficult to make a statement for HMF contents of honey types unless they are harvested, processed, and stored under the same conditions.

\section{Proline content}

Proline is the most abundant amino acid (50-85\% of total) out of the 26 identified in honey [49]. According to TFC [33], the minimum proline content must be $300 \mathrm{mg} / \mathrm{kg}$ in general. However, there are exceptional regulations for some unifloral honey types such as chestnut $(\geq 500 \mathrm{mg} / \mathrm{kg})$, acacia $(\geq 120 \mathrm{mg} / \mathrm{kg})$, and lavender $(\geq 180 \mathrm{mg} / \mathrm{kg})$ since proline content is also associated with its floral and botanical origin [50]. Considerably lower proline concentrations, as proline content decreases with storage, usually indicates ripeness and shows adulteration with sugar due to significantly lower proline content of syrup compared to nectars. Czipa et al. [41] showed that heating acacia honey for $60 \mathrm{~min}$ at $80{ }^{\circ} \mathrm{C}$ results in $\approx 10 \%$ loss of proline. Considering current results, all proline contents are found to be in compliance with the regulations of TFC [33] (Table 2). Honey type significantly affected the proline concentration of honey samples $(\mathrm{p}=0.001)$. The highest proline levels were detected in the chestnut $(758.56 \pm 67.73 \mathrm{mg} / \mathrm{kg})$ and multifloral $(692.67 \pm 79.53 \mathrm{mg} / \mathrm{kg})$ honey, respectively while the lowest one was in acacia honey $(357.00 \pm 34.38 \mathrm{mg} / \mathrm{kg})$. Accordingly, acacia honey was reported to have the lowest proline content among floral honey by Földházi et al. [51]. Similar results were obtained for acacia, chestnut, and rhododendron honey in different studies $[18,19,35,52,53]$.

\section{Antioxidant activity}

Antioxidant activities of honey samples are presented in Table 3. Antioxidant activity was determined using both DPPH and FRAP which showed a weak to moderate correlation $(r=0.371)$. Although no significant difference was detected between antioxidant activities by the FRAP method ( $p>0.05)$, multifloral honey had significantly higher antioxidant activity according to the DPPH method $(\mathrm{p}<0.05)$. However, it cannot be ignored that the standard deviation values are quite high in almost all honey samples. Overall, it would be proper to mention that multifloral was the honey type possessing the highest antioxidant activity considering both test results. Similar rates were obtained in different studies for chestnut, multifloral, and acacia honey regarding FRAP activity [19, 38, 54]. Gül and Pehlivan [55] determined the DPPH radical scavenging activity of honey samples collected from Ordu as rhododendron $>$ chestnut $>$ acacia. Simultaneous collection of honey samples and storage under controlled conditions (temperature, humidity, light, etc.) are required to make a logical assessment of the antioxidant activity of honey samples [46].

\section{Total phenolic content}

Total phenolic contents varied greatly among the honey types (Table 3 ) and honey type affected the phenolic content significantly $(\mathrm{p}<0.05)$. The lowest phenolic content
Table 3 Antioxidant activities and total phenolic contents of honey samples

\begin{tabular}{llcrr}
\hline Parameter & Honey samples & Mean value \pm SD & Min & Max \\
\hline FRAP activity (mg TE/g honey) & Multifloral honey & $1.34 \pm 0.51^{\mathrm{a}}$ & 0.64 & 1.81 \\
& Chestnut & $1.49 \pm 0.14^{\mathrm{a}}$ & 1.28 & 1.63 \\
& Acacia & $0.68 \pm 0.03^{\mathrm{a}}$ & 0.65 & 0.72 \\
& Rhododendron & $0.86 \pm 0.22^{\mathrm{a}}$ & 0.57 & 1.17 \\
& - X \pm SD & $1.09 \pm 0.44$ & 0.57 & 1.81 \\
DPPH activity (\% inhibition) & Multifloral honey & $30.68 \pm 0.36^{\mathrm{a}}$ & 30.43 & 30.94 \\
& Chestnut & $2.51 \pm 1.47^{\mathrm{b}}$ & 0.95 & 3.54 \\
& Acacia & $7.56 \pm 5.02^{\mathrm{b}}$ & 2.35 & 11.97 \\
& Rhododendron & $11.67 \pm 5.47^{\mathrm{b}}$ & 6.37 & 17.31 \\
Total phenolic content & - & $11.09 \pm 10.91$ & 0.95 & 30.94 \\
(mg GAE/g) & Multifloral honey & $0.26 \pm 0.07^{\mathrm{a}}$ & 0.15 & 0.36 \\
& Chestnut & $0.12 \pm 0.03^{\mathrm{bc}}$ & 0.09 & 0.16 \\
& Acacia & $0.02 \pm 0.01^{\mathrm{c}}$ & 0.01 & 0.03 \\
& Rhododendron & $0.19 \pm 0.06^{\mathrm{ab}}$ & 0.11 & 0.32 \\
& - & $0.15 \pm 0.10$ & 0.01 & 0.36 \\
\hline
\end{tabular}

Mean values in the same column followed by different uppercase letters are significantly different $(\mathrm{p}<0.05)$ $S D$ standard deviation, $T E$ trolox equivalent 
Table 4 Correlations between TPC and antioxidant activities of DPPH and FRAP

\begin{tabular}{llll}
\hline & FRAP activity & DPPH activity & TPC \\
\hline FRAP activity & & & \\
$r$ & 1 & 0.371 & 0.575 \\
$p$ & & 0.235 & $0.05^{*}$ \\
DPPH activity & & & \\
$r$ & 0.371 & 1 & 0.697 \\
$p$ & 0.235 & & 0.012 \\
TPC & & & \\
$r$ & 0.575 & 0.697 & 1 \\
$p$ & $0.05^{*}$ & $0.012^{*}$ & \\
\hline
\end{tabular}

Asterisks (*) represent significant differences $(\mathrm{p}<0.05)$

$r$ Pearson's correlation coefficient, $p \mathrm{p}$ value

was determined in acacia honey $(0.02 \pm 0.01)$ while the highest one was in multifloral honey $(0.26 \pm 0.07)$ with more than tenfold difference (Table 3 ). According to the phenolic contents, honey samples are ordered as mulfifloral $>$ rhododendron $>$ chestnut $>$ acacia. Acacia honey was found to have the lowest TPC compared to chestnut and/ or rhododendron honey in previous studies [18, 19, 54]. Czipa et al. [41], determined an average TPC of $0.17 \mathrm{mg} / \mathrm{g}$ from 44 Hungarian acacia honey. Parallel to the current results, an average TPC of $0.05 \mathrm{mg} / \mathrm{g}$ was determined in a study by Bertoncelj et al. [54] while averages of $0.16 \mathrm{mg} / \mathrm{g}$ and $0.19 \mathrm{mg} / \mathrm{g}$ were detected for acacia honey in the studies by Can et al. [19] and Kivrak et al. [18], respectively. Considering rhododendron honey, Silici et al. [56] found an average TPC of $0.21 \mathrm{mg} / \mathrm{g}$ from 7 honey samples collected from Ordu. In another study, chlorogenic acid and coumaric acid were found to be the main phenolic compounds in 12 rhododendron honey collected from the Black Sea region while ferulic acid was the most abundant phenolic in the honey $(n=2)$ collected from Ordu [57]. Kolayli et al. [58] determined the TPC of chestnut honey $(\mathrm{n}=15)$ as $4.3 \mathrm{mg} / \mathrm{g}$ which is considerably higher than our results. Although Gül and Pehlivan [55] determined the TPC of rhododendron to be higher than chestnut, which is similar to the current findings, there are also studies in which the TPC of chestnut honey was determined to be higher than rhododendron $[18,38]$. These differences could be attributed to seasonal and regional varieties of honey samples. Furthermore, correlation analysis indicated that TPC is in moderate correlation with antioxidant activities, both FRAP $(r=0.575)$ and DPPH $(r=0.697)$ (Table 4$)$. The TPC and antioxidant activity usually show a good correlation $[54,59,60]$ although there are studies indicating moderate correlation [61].

\section{Conclusions}

Unifloral honey such as chestnut, acacia, and rhododendron are accepted as higher quality honey due to their pure flavors while multifloral honey is a mixture of different flavors comprising its own unique flavor every time. Therefore, it is important to physicochemically characterize these honeys in order to identify their quality and purity together with possible adulteration. In compliance with former studies, this study gives a general idea of the properties of multifloral (plateau), chestnut, rhododendron, and acacia honey. Considering the previous studies it could be proper to say that although seasonal and regional differences affect the quality of each honey, all honey types have their unique characteristics. Further studies embracing sugar, phenolic, and aromatic profiles and thermal behaviors of honey are required for a deeper investigation and revelation of distinctive features.

Acknowledgements The authors are indebted to Ordu University Scientific Research Projects Coordination Unit (ODU/BAP, Grant No: TF-1649) for financial support of this work. Also, we would like to express our gratitude to the Ordu Apiculture Research Institute for their full support in conducting this study. Finally, the authors would like to thank Dr. Mutlu SÖNMEZ ÇELEBİ for her contribution to the English language review and editing of the manuscript.

Author contributions LK designed the study, critically evaluated the results, and wrote the manuscript. NA performed the analyses using the selected methods and wrote the first draft of the manuscript. OFC contributed to the statistical evaluation of the data, the discussion of the findings, and the writing of the manuscript. All authors read and approved the final version of the manuscript.

\section{Declarations}

Conflict of interest The authors declare that they have no conflicts of interest.

\section{References}

1. J.M. Alvarez-Suarez, S. Tulipani, D. Díaz, Y. Estevez, S. Romandini, F. Giampieri, E. Damiani, P. Astolfi, S. Bompadre, M. Battino, Food Chem. Toxicol. 48(8-9), 2490-2499 (2010)

2. F.M. Bueno-Costa, R.C. Zambiazi, B.W. Bohmer, F.C. Chaves, W.P. da Silva, J.T. Zanusso, I. Dutra, LWT-Food Sci. Technol. 65, 333-340 (2016)

3. N. Gheldof, N.J. Engeseth, J. Agric. Food Chem. 50(10), 30503055 (2002)

4. S. Gomes, L.G. Dias, L.L. Moreira, P. Rodrigues, L. Estevinho, Food Chem. Toxicol. 48(2), 544-548 (2010)

5. S. Huttunen, K. Riihinen, J. Kauhanen, C. Tikkanen-Kaukanen, APMIS 121(9), 827-834 (2013)

6. A. Osho, O. Bello, Asian J. Exp. Biol. Sci. 1, 875-880 (2010)

7. R.F. El-Kased, R.I. Amer, D. Attia, M. Elmazar, Sci. Rep. 7(1), 1-11 (2017)

8. B.A. Minden-Birkenmaier, G.L. Bowlin, Bioengineering 5(2), 46 (2018) 
9. H. Ali, M. Abu Bakar, M. Majid, N. Muhammad, S. Lim, Food Res. 4(5), 1421-1426 (2020)

10. A.K. Hassan, D.A. El-kotby, M.M. Tawfik, R.E. Badr, I.M. Bahgat, J. Basic Appl. Zool. 80(1), 58 (2019)

11. F.C. Biluca, B. da Silva, T. Caon, E.T.B. Mohr, G.N. Vieira, L.V. Gonzaga, L. Vitali, G. Micke, R. Fett, E.M. Dalmarco, Food Res. Int. 129, $108756(2020)$

12. J.C. Ruiz-Ruiz, A.J. Matus-Basto, P. Acereto-Escoffié, M.R. Segura-Campos, Food Agr. Immunol. 28(6), 1424-1437 (2017)

13. S. Ahmed, N.H. Othman, BMC Complement. Altern. Med. 17(1), 208 (2017)

14. D. Cianciosi, T.Y. Forbes-Hernández, S. Afrin, M. Gasparrini, J.L. Quiles, E. Gil, S. Bompadre, J. Simal-Gandara, M. Battino, F. Giampieri, Antioxidants 9(1), 64 (2020)

15. L.M. Brutscher, K.F. Daughenbaugh, M.L. Flenniken, Curr. Opin. Insect Sci. 10, 71-82 (2015)

16. S. Bogdanov, Antiviral properties of the bee products: a review. Bee products against viruses and for covid-19 prevention (review), (2020)

17. S. Bogdanov, T. Jurendic, R. Sieber, P. Gallmann, J. Am. Coll. Nutr. 27(6), 677-689 (2008)

18. Ş. Kivrak, I. Kivrak, E. Karababa, Food Sci. Technol. 37(1), 80-89 (2017)

19. Z. Can, O. Yildiz, H. Sahin, E.A. Turumtay, S. Silici, S. Kolayli, Food Chem. 180, 133-141 (2015)

20. Anonymous, Turkey honey production statistics of year 2019. Republic of Turkey Ministry of Agriculture and Forestry Research Institute of Beekeeping, (2020)

21. M. Al-Mamary, A. Al-Meeri, M. Al-Habori, Nutr. Res. 22(9), 1041-1047 (2002)

22. T. Kahraman, S.K. Buyukunal, A. Vural, S.S. Altunatmaz, Food Chem. 123(1), 41-44 (2010)

23. S. Bogdanov, Harmonised Methods of the International Honey Commision (Swiss Bee Research Center, International Honey Commission, World Network of Honey Science: 63 str, Bern, 2009).

24. E. Derebaşı, G. Bulut, M. Col, F. Güney, N. Yaşar, Ö. Ertürk, Fresen. Environ. Bull. 23(1), 10-17 (2014)

25. N. Sakač, M. Sak-Bosnar, Talanta 93, 135-138 (2012)

26. TSI, Determination of Proline Content of Honey (Turkish Standard Institute, Ankara, 2008).

27. G. Bergamo, S.K.T. Seraglio, L.V. Gonzaga, R. Fett, A.C.O. Costa, Food Res. Int. 116, 745-754 (2019)

28. O. Sagdic, S. Silici, L. Ekici, Int. J. Food Prop. 16(3), 658-666 (2013)

29. İ. Gülçin, İ.G. Şat, Ş. Beydemir, M. Elmastaş, Ö.İ Küfrevioğlu, Food Chem. 87(3), 393-400 (2004)

30. L. Bicudo de Almeida-Muradian, O. Monika Barth, V. Dietemann, M. Eyer, A.S. Freitas, A.-C. Martel, G.L. Marcazzan, C.M. Marchese, C. Mucignat-Caretta, A. Pascual-Maté, J. Apic. Res. 59(3), $1-62(2020)$

31. A.A. Machado De-Melo, L.B. Almeida-Muradian, M.T. Sancho, A. Pascual-Maté, J. Apic. Res. 57(1), 5-37 (2018)

32. S. Bogdanov, Elaboration and harvest of honey, in The book of honey. Bee product science. (2011), pp. 8-14

33. TFC, Turkish food codex honey notification (Turkish Food Codex, 2020)
34. EU, European Union Honey Directive (2001)

35. G. Šarić, D. Matković, M. Hruškar, N. Vahčić, Food Technol. Biotechnol. 46(4), 355-367 (2008)

36. M. Zappala, B. Fallico, E. Arena, A. Verzera, Food Control 16(3), 273-277 (2005)

37. V. Kaškonienė, P.R. Venskutonis, Compr. Rev. Food Sci. Food Saf. 9(6), 620-634 (2010)

38. M. Küçük, S. Kolaylı, Ş Karaoğlu, E. Ulusoy, C. Baltacı, F. Candan, Food Chem. 100(2), 526-534 (2007)

39. A. Thrasyvoulou, J. Manikis, Apidologie 26(6), 441-452 (1995)

40. I.N. Pasias, I.K. Kiriakou, C. Proestos, Food Chem. 229, 425-431 (2017)

41. N. Czipa, C.J. Phillips, B. Kovács, J. Food Sci. Technol. 56(3), 1245-1255 (2019)

42. L.P. Oddo, E. Baldi, M. Accorti, Apidologie 21(1), 17-24 (1990)

43. M. Zarei, A. Fazlara, N. Tulabifard, Heliyon 5(6), e01894 (2019)

44. G.S. Sodré, L.C. Marchini, A.C.C.C. Moreti, I.P. Otsuk, C.A.L. Carvalho, Rev. Bras. Zootec. 40(8), 1837-1843 (2011)

45. A. Kesić, A. Crnkić, Z. Hodžić, N. Ibrišimović, A. Šestan, J. Sci. Res. Rep. 3, 1057-1066 (2014)

46. M. Zarei, A. Fazlara, N. Alijani, Funct. Foods Health Dis. 9(9), 593-605 (2019)

47. M.B. Sakač, P.T. Jovanov, A.Z. Marić, L.L. Pezo, ŽS. Kevrešan, A.R. Novaković, N.M. Nedeljković, Food Chem. 276, 15-21 (2019)

48. A. Chakir, A. Romane, G.L. Marcazzan, P. Ferrazzi, Arab. J. Chem. 9, S946-S954 (2016)

49. H.-D. Belitz, W. Grosch, P. Schieberle, Sugars, sugar alcohols and honey, in Food chemistry. (Springer, Berlin, 2009)

50. J. Kečkeš, J. Trifković, F. Andrić, M. Jovetić, Ž Tešić, D. Milojković-Opsenica, J. Sci. Food Agric. 93(13), 3368-3376 (2013)

51. G. Földházi, M. Amtmann, P. Fodor, A. Ittzés, Acta Aliment. 25(3), 237-256 (1996)

52. N. Czipa, M. Borbély, Z. Győri, Acta Aliment. 41(1), 26-32 (2012)

53. É. Széles, M. Borbély, D. Hovánszki, A. Tisza, Z. Győri, Cereal Res. Commun. 35(2), 1153-1156 (2007)

54. J. Bertoncelj, U. Doberšek, M. Jamnik, T. Golob, Food Chem. 105(2), 822-828 (2007)

55. A. Gül, T. Pehlivan, Saudi J. Biol. Sci. 25(6), 1056-1065 (2018)

56. S. Silici, O. Sagdic, L. Ekici, Food Chem. 121(1), 238-243 (2010)

57. S. Silici, K. Sarioglu, M. Dogan, K. Karaman, Int. J. Food Prop. 17(5), 1126-1135 (2014)

58. S. Kolayli, R. Aliyazicioglu, E. Ulusoy, S. Karaoglu, Hacet. J. Biol. Chem. 36, 163-172 (2008)

59. M. Halagarda, S. Groth, S. Popek, S. Rohn, V. Pedan, Antioxidants 9(1), 44 (2020)

60. H. Ibrahimi, A. Hajdari, J. Apic. Res. 59, 452-457 (2020)

61. M. Al-Farsi, A. Al-Amri, A. Al-Hadhrami, S. Al-Belushi, Heliyon 4(10), e00874 (2018)

Publisher's Note Springer Nature remains neutral with regard to jurisdictional claims in published maps and institutional affiliations. 